University of Nebraska - Lincoln

DigitalCommons@University of Nebraska - Lincoln

\title{
A late Quaternary record of eolian silt deposition in a maar lake, St. Michael Island, western Alaska
}

Daniel R. Muhs

U.S. Geological Survey, dmuhs@usgs.gov

Thomas A. Ager

U.S. Geological Survey, tager@usgs.gov

Josh Been

U.S. Geological Survey

J. Platt Bradbury

Walter E. Dean

U.S. Geological Survey

Follow this and additional works at: https://digitalcommons.unl.edu/usgsstaffpub

Part of the Earth Sciences Commons

Muhs, Daniel R.; Ager, Thomas A.; Been, Josh; Bradbury, J. Platt; and Dean, Walter E., "A late Quaternary record of eolian silt deposition in a maar lake, St. Michael Island, western Alaska" (2003). USGS Staff -Published Research. 175.

https://digitalcommons.unl.edu/usgsstaffpub/175

This Article is brought to you for free and open access by the US Geological Survey at DigitalCommons@University of Nebraska - Lincoln. It has been accepted for inclusion in USGS Staff -- Published Research by an authorized administrator of DigitalCommons@University of Nebraska - Lincoln. 


\title{
A late Quaternary record of eolian silt deposition in a maar lake, St. Michael Island, western Alaska
}

\author{
Daniel R. Muhs, ${ }^{\mathrm{a}, *}$ Thomas A. Ager, ${ }^{\mathrm{a}}$ Josh Been, ${ }^{\mathrm{a}}$ J. Platt Bradbury, ${ }^{\mathrm{b}}$ and Walter E. Dean ${ }^{\mathrm{c}}$ \\ ${ }^{a}$ U.S. Geological Survey, MS 980, Box 25046, Federal Center, Denver, CO 80225, USA \\ b 5784 Horseradish Gulch, Golden, CO 80403, USA \\ ${ }^{\mathrm{c}}$ U.S. Geological Survey, MS 980, Box 25046, Federal Center, Denver, CO 80225, USA
}

Received 7 November 2002

\begin{abstract}
Recent stratigraphic studies in central Alaska have yielded the unexpected finding that there is little evidence for full-glacial (late Wisconsin) loess deposition. Because the loess record of western Alaska is poorly exposed and not well known, we analyzed a core from Zagoskin Lake, a maar lake on St. Michael Island, to determine if a full-glacial eolian record could be found in that region. Particle size and geochemical data indicate that the mineral fraction of the lake sediments is not derived from the local basalt and is probably eolian. Silt deposition took place from at least the latter part of the mid-Wisconsin interstadial period through the Holocene, based on radiocarbon dating. Based on the locations of likely loess sources, eolian silt in western Alaska was probably deflated by northeasterly winds from glaciofluvial sediments. If last-glacial winds that deposited loess were indeed from the northeast, this reconstruction is in conflict with a model-derived reconstruction of paleowinds in Alaska. Mass accumulation rates in Zagoskin Lake were higher during the Pleistocene than during the Holocene. In addition, more eolian sediment is recorded in the lake sediments than as loess on the adjacent landscape. The thinner loess record on land may be due to the sparse, herb tundra vegetation that dominated the landscape in full-glacial time. Herb tundra would have been an inefficient loess trap compared to forest or even shrub tundra due to its low roughness height. The lack of abundant, full-glacial, eolian silt deposition in the loess stratigraphic record of central Alaska may be due, therefore, to a mimimal ability of the landscape to trap loess, rather than a lack of available eolian sediment.
\end{abstract}

(C) 2003 University of Washington. Published by Elsevier Inc. All rights reserved.

Keywords: Alaska; St. Michael Island; Lake sediments; Loess; Geochemistry; Paleoclimate; Last-glacial period

\section{Introduction}

Eolian sediments (sand and loess) constitute one of the most important terrestrial records of climate change. Windblown sediments are sensitive to overall moisture balance, land-surface stability and degree of vegetation cover. In addition, they are direct records of past atmospheric circulation patterns. Loess is one of the most extensive surficial deposits of Alaska (Fig. 1). Although eolian silt is found over much of the state, most studies have been concerned primarily with the thick loess deposits of central Alaska, near Fairbanks (Péwé, 1955, 1975; Begét, 1990; Westgate

* Corresponding author. Fax: +1-303-236-5349.

E-mail address: dmuhs@usgs.gov (D.R. Muhs). et al., 1990; Muhs et al., 2003). The eolian silt deposits of most of the rest of Alaska have received comparatively little study.

In most parts of midcontinental North America, loess of last-glacial (late Wisconsin, or marine oxygen isotope stage 2) age is far thicker than mid-Wisconsin or pre-Wisconsin loesses. Late Wisconsin loess in the midcontinental region is often ten meters thick and sometimes reaches a thickness of several tens of meters (see Muhs and Bettis, 2000, and Muhs et al., 1999, for examples from Colorado, Nebraska and Iowa). In contrast, stratigraphic studies in the Fairbanks area show that loess of late Wisconsin age may be either very thin (compared to Holocene or mid-Wisconsin loesses) or nonexistent in many sections (Begét, 1990; Muhs et al., 2003). Begét (1988) suggested that the record of thin, fullglacial-age loess in central Alaska could be the result of 


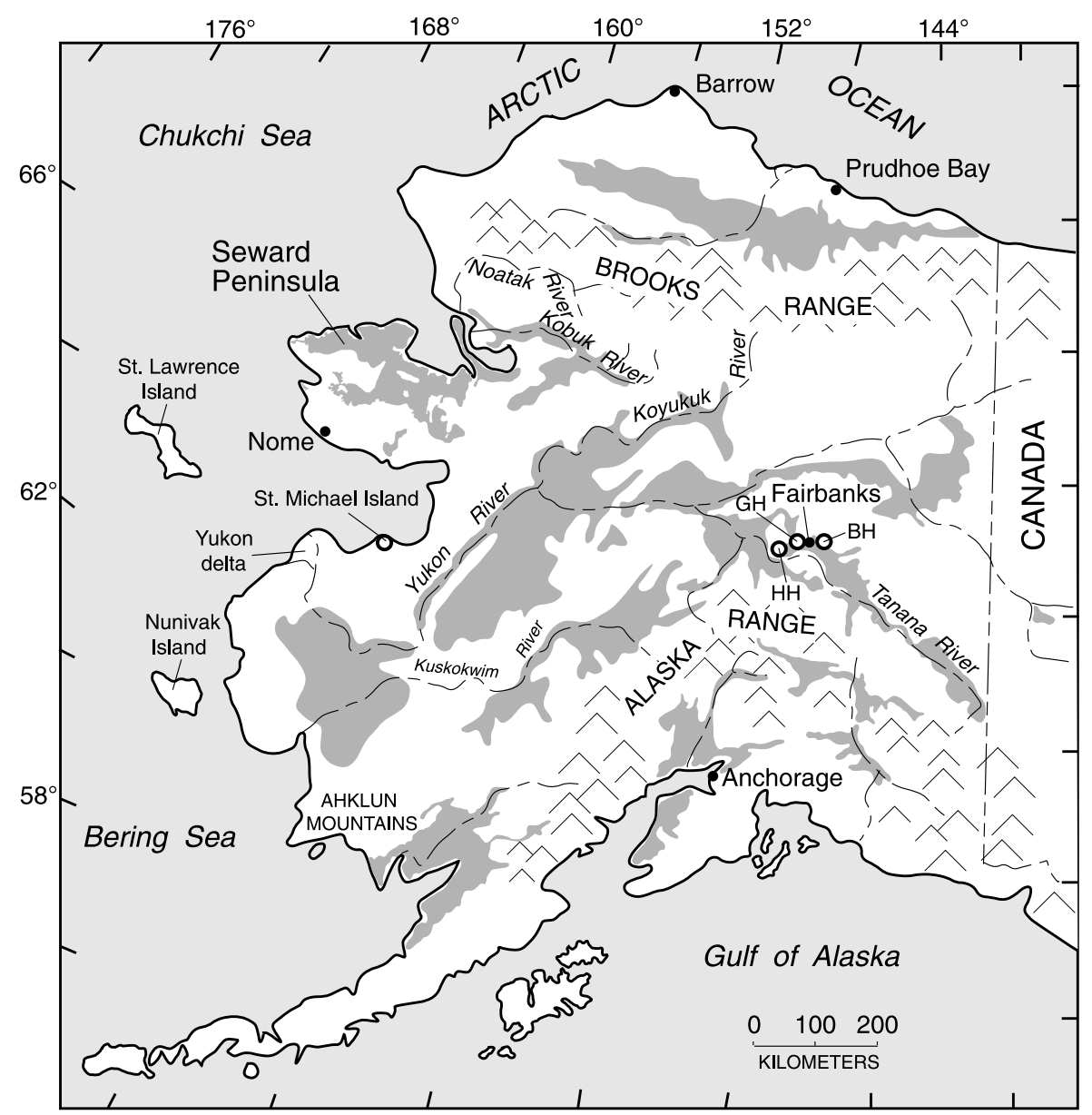

Fig. 1. Map showing the distribution of known loess deposits in Alaska and location of St. Michael Island. Loess distribution complied from Hopkins (1963) and Sainsbury (1972) for the Seward Peninsula and Péwé (1975) for all other parts of the region. Fairbanks-area loess localities: HH, Halfway House; GH, Gold Hill; BH, Birch Hill (see Muhs et al., 2003).

either erosion during the early Holocene or inefficient trapping of loess particles by a sparse herb tundra vegetation. A question that arises from these studies is how widespread this stratigraphic anomaly (thin loess deposits of last-glacial age) is over the rest of Alaska.

Loess is widespread in western Alaska (Figs. 1,2) and although few studies exist for this region, they suggest that a valuable stratigraphic record may be present (Hopkins, 1963; McCulloch and Hopkins, 1966; Höfle et al., 2000). Furthermore, recent studies on the northern Seward Peninsula suggest that loess of last-glacial age is indeed present in the region and is widespread, although thicknesses are not well known (Höfle and Ping, 1996; Höfle et al., 2000). Exposures of loess are rare in western Alaska and shallow permafrost in this tundra-dominated region precludes easy excavation. An alternative method of deciphering the eolian record is to examine the wind-blown component of lacustrine sediments. In both midcontinental North America (Dean, 1997) and Asia (Xiao et al., 1997), investigators have demonstrated that, under favorable circumstances, it is possible to obtain long and detailed eolian records from lake sediments. Furthermore, unlike loess deposits, which are subject to either erosion (resulting in incomplete records) or colluvial reworking (resulting in mixed stratigraphy), lacustrine records typically contain few or no unconformities and usually contain sufficient organic matter for radiocarbon dating at multiple intervals.

We analyzed a core from Zagoskin Lake, on St. Michael Island, western Alaska (Figs. 1, 2), as a test to see if an eolian record, particularly for the late Wisconsin period, could be obtained. A core from this particular locality was chosen because (1) it is in a part of Alaska that was not glaciated recently (Fig. 2) and therefore could have a relatively long sedimentary record; (2) it is situated in a lowrelief terrain (Fig. 3), such that colluvial or fluvial sediment inputs to the lake are minimal; (3) the bedrock of the area is basalt (Fig. 4), easily distinguished mineralogically and geochemically from eolian sediments that are usually felsic; and (4) the lake sediments preserve a detailed pollen record spanning $\geq 30,000 \mathrm{yr}$ (see Ager, this volume), which allows inferences about the environmental conditions of eolian deposition. We also made comparative geochemical studies 


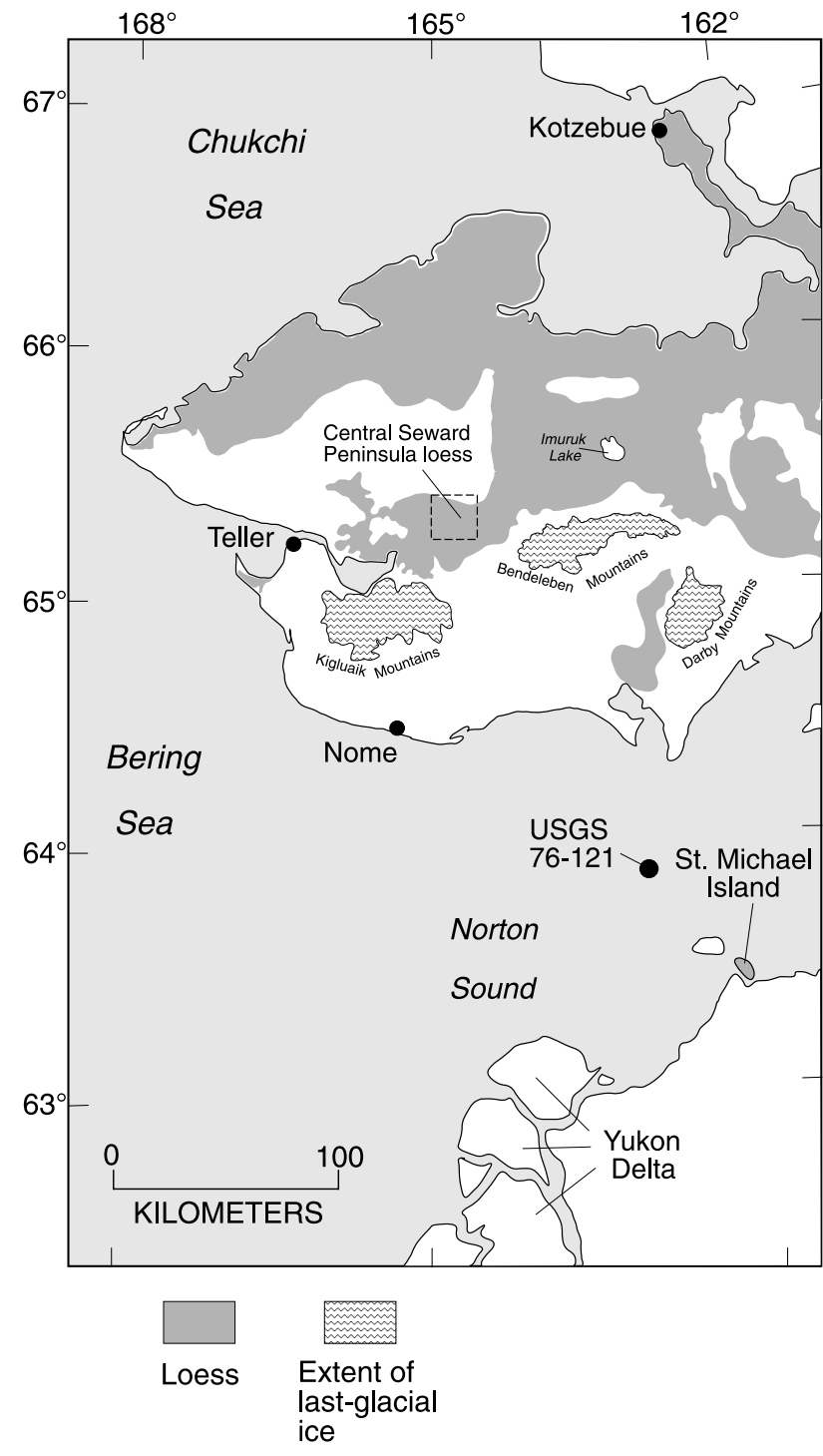

Fig. 2. Map of a portion of western Alaska showing the extent of loess cover and late Wisconsin glacial ice and study localities: St. Michael Island, USGS core 76-121, and loess in the central Seward Peninsula. Loess and glacier distribution compiled from Hopkins (1963), Sainsbury (1972), and Péwé (1975).

with loess sampled in the central part of the Seward Peninsula and with cored sediments of last-glacial age from Norton Sound (Fig. 2).

\section{Study area, methods and chronology}

St. Michael Island is situated in Norton Sound, northern Bering Sea, and is northeast of the modern distributary system of the Yukon River (Figs. 1, 2). The island is of Quaternary age, and consists of Quaternary basalt and pyroclastic deposits. Basalt flows are exposed at the surface in several areas (Fig. 4) and also underlie a peat mantle on the island. The basalt is black or dark-gray, fine-grained, por- phyritic and vesicular and is interpreted to be tholeiitic (Hoare and Condon, 1971). The latter workers described the basalt mineralogy as consisting of olivine and clinopyroxene phenocrysts occurring in a groundmass of labradorite, clinopyroxene, glass and probable magnetite. Although not mapped by Péwé (1975) in his loess compilation for Alaska, Hoare and Condon (1971) noted that a meter or more of silt, interpreted to be of eolian origin, mantles much of St. Michael Island. We also observed loess overlying volcanic deposits in coastal exposures of St. Michael Island.

The surface of St. Michael Island is characterized by several striking maar craters (Fig. 4) which are the repositories of sediment records discussed here and by Ager (1982, 1983 and this volume). Maars are formed by explosive excavation into older rocks during phreatomagmatic eruptions and the largest ones on Earth occur on the Seward Peninsula in western Alaska (Begét et al., 1996). One of the maar lakes on St. Michael Island, Puyuk Lake (Fig. 3), has an $\sim 16,000$-yr-long pollen record that was described by Ager (1982). His record shows a basal Herb Zone, dated to the last glacial period, that is characterized by a predominance of Poaceae, Cyperaceae, Salix and Artemisia pollen. The Herb Zone is succeeded by a Betula Zone that existed from the late-glacial period to the early Holocene. A third zone, designated the Alnus Zone, characterizes the midHolocene up to the present. A more complex pollen record is found in Zagoskin Lake (Fig. 3), reported by Ager (1983). A 5.3-m-long segment of core from this lake has the same three pollen zones as Puyuk Lake, but Ager (1983) also recognized a Populus-Salix Zone that succeeded the Betula Zone, in turn followed by a Betula-Ericaceae Zone that preceded the Holocene Alnus Zone. A longer and more detailed pollen record for St. Michael Island is now available from Zagoskin Lake (Ager, this volume). At present, St. Michael Island is mantled by peat deposits and mesic low-shrub tundra with scattered thickets of willow (Salix) and alder (Alnus) in protected sites.

For the present study, a 15.2-m-long core was raised from Zagoskin Lake in March, 1979, using the frozen lake surface as a coring platform. Whole-sediment splits from the core were taken for major element chemistry (wavelength-dispersive X-ray fluorescence), trace element chemistry (energy-dispersive X-ray fluorescence), mineralogy (X-ray diffractometry, using random-orientation mounts), and particle size distribution. Particle size distribution was done by laser diffraction granulometry after destruction of organic matter with hydrogen peroxide and dispersion with sodium hexametaphosphate. No carbonate minerals were present, based on the X-ray analyses; thus, no hydrochloric acid pretreatments were necessary. Biogenic silica abundances were determined by the same methods used by Colman et al. (1995) and were recently reported by Bradbury et al. (2001).

Splits from the core were also taken for radiocarbon dating of organic matter in the USGS laboratories in Reston, VA. All analyses were done by conventional beta counting. 


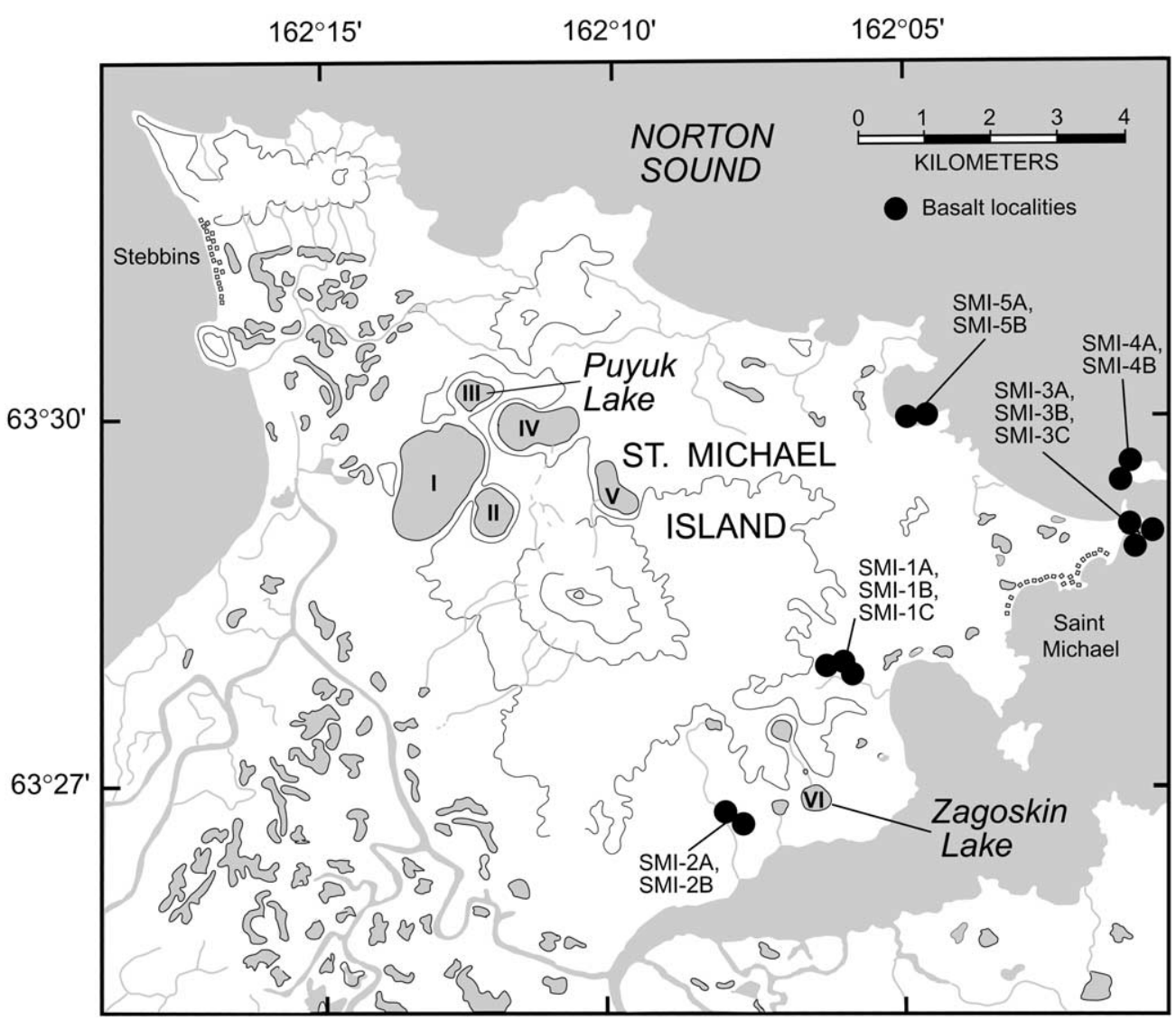

Fig. 3. Generalized topographic map of St. Michael Island, Alaska, showing location of Zagoskin Lake, other maar and non-maar lakes, elevations (contour interval $=100 \mathrm{ft} .=30.5 \mathrm{~m})$, and basalt sample localities.

Results show that the core from Zagoskin Lake spans all of the Holocene and last glacial period and extends into the latter part of the mid-Wisconsin interstadial interval (Table 1). All ages are in correct stratigraphic order with the possible exception of samples W-4930 $(1108-1119 \mathrm{~cm})$ and W-4630 (1191-1215 cm). These two samples have apparent ages that are reversed stratigraphically, but are within analytical uncertainty of each other. In addition, sample $\mathrm{W}-4928$ may be $\sim 1,000{ }^{14} \mathrm{C}$ yr too young. Ager (this volume) points out that this depth $(490-500 \mathrm{~cm})$ is where there is a shift in pollen assemblages from the Herb Zone to the Betula Zone. In most other localities of western Alaska, this vegetation transition is about 1,000 yr younger than the $\sim 15,000{ }^{14} \mathrm{C}$ yr B.P. age of sample W-4928. All ages were calibrated to a calendar-year timescale using the program of Stuiver et al. (1998) for the part of the record younger than $\sim 20,000{ }^{14} \mathrm{C}$ yr B.P. For the older part of the record, we give approximate calendar-year age estimates using the record given by Voelker et al. (2000).

\section{Particle size distribution}

Laser diffraction granulometry shows that the sediments of Zagoskin Lake are very fine-grained (Fig. 5). The mean particle size is relatively uniform throughout the core and all samples have mean values that fall within the range of fine silt (6 to 7 phi). Studies have shown that laser diffraction particle size analyses do not always agree with particle size analyses conducted by conventional sieve and pipette methods (see summary in Buurman et al., 1997). Thus, we have limited our comparisons to loess from eastern Colorado, southern Mississippi, France and China, all of which have been analyzed by laser-derived particle size methods.

In general, sediments from Zagoskin Lake have both mean particle sizes and degrees of sorting that are similar to loess (Fig. 5). Zagoskin Lake sediments are much finer than loess from France and somewhat finer grained than loess of last-glacial age from Natchez and Vicksburg, Mississippi. The Natchez and Vicksburg localities are $\sim 5 \mathrm{~km}$ from their source, which is the Mississippi River valley. Zagoskin Lake sediments are also finer grained than last-glacial-age loess at Beecher Island, Colorado. The Beecher Island locality is $\sim 120 \mathrm{~km}$ downwind of its source sediments (Aleinikoff et al., 1999; Muhs et al., 1999). Zagoskin Lake sediments are better sorted than Colorado loess, which has two sources, but not as well sorted as southern Mississippi loess, which has a single source. Although it is somewhat finer grained, the degree of sorting of Zagoskin Lake sedi- 


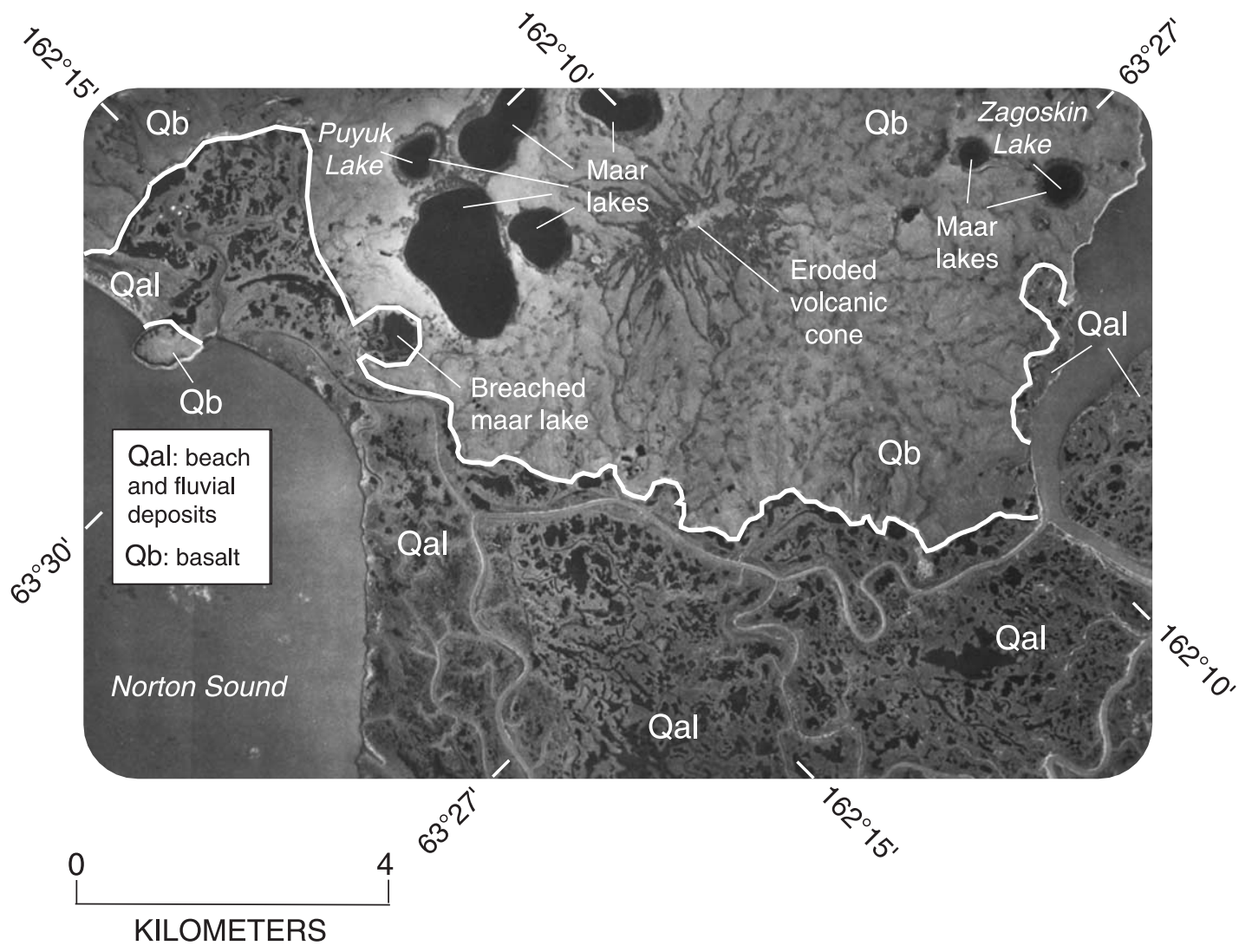

Fig. 4. Aerial photograph of a part of St. Michael Island showing Zagoskin Lake, other maar lakes and simplified geology. Qb, basalt; Qal, beach and fluvial deposits.

ments is not significantly different than that in Chinese loess.

\section{Mineralogy and geochemistry}

The basalt that forms St. Michael Island is characterized by a typically mafic mineral assemblage, including olivine, clinopyroxene, plagioclase (labradorite), magnetite and glass (Hoare and Condon, 1971). X-ray diffraction analysis of Zagoskin Lake sediments shows a significant contrast in mineralogy compared to the host basalt. Although plagioclase is present in the lake sediments, quartz is present at all depths and is dominant at most depths. Except for the depth intervals from $12-15 \mathrm{~cm}, 103-106 \mathrm{~cm}$, and $190-193 \mathrm{~cm}$, measurable amounts of mica are also present in Zagoskin Lake sediments.

Major element geochemical analyses support the differ-

Table 1

Radiocarbon ages and calibrated radiocarbon ages from Zagoskin Lake, St. Michael Island, Alaska

\begin{tabular}{llcclc}
\hline Laboratory \# & Material & Depth $(\mathrm{cm})$ & $\begin{array}{l}\text { Radiocarbon age }( \pm 1 \sigma) \\
{ }^{14} \text { C yr B.P. }\end{array}$ & $\begin{array}{l}\text { Calibrated age }(2 \sigma) \\
\text { cal yr B.P. }\end{array}$ & Calibration reference \\
\hline W-4929 & Organic matter & $129-140$ & $4830 \pm 80$ & $5723(5591) 5327$ & Stuiver et al. (1998) \\
W-4625 & Organic matter & $166-181$ & $6430 \pm 90$ & $7554(7368) 7163$ & Stuiver et al. (1998) \\
W-4931 & Organic matter & $230-244$ & $8120 \pm 110$ & $9422(9028) 8645$ & Stuiver et al. (1998) \\
W-4915 & Organic matter & $374-389$ & $11,060 \pm 100$ & $13,348(13,022) 12,666$ & Stuiver et al. (1998) \\
W-4928 & Organic matter & $490-500$ & $14,970 \pm 170$ & $18,595(17,907)$ 17,281 & Stuiver et al. (1998) \\
W-4918 & Organic matter & $591-605$ & $15,110 \pm 120$ & $18,704(18,068)$ 17,496 & Stuiver et al. (1998) \\
W-4642 & Organic matter & $781-804$ & $21,500 \pm 250$ & $\sim 24,000$ & Voelker et al. (2000) \\
W-4640 & Organic matter & $955-980$ & $23,900 \pm 240$ & $\sim 27,000$ & Voelker et al. (2000) \\
W-4930 & Organic matter & $1108-1119$ & $25,800 \pm 400$ & $\sim 29,000$ & Voelker et al. (2000) \\
W-4630 & Organic matter & $1191-1215$ & $25,690 \pm 420$ & $\sim 29,000$ & Voelker et al. (2000) \\
W-4925 & Organic matter & $1335-1350$ & $27,750 \pm 550$ & $>31,000$ & Voelker et al. (2000) \\
W-4379 & Organic matter & $1490-1520$ & $>39,000$ & Voelker et al. (2000) \\
\hline
\end{tabular}




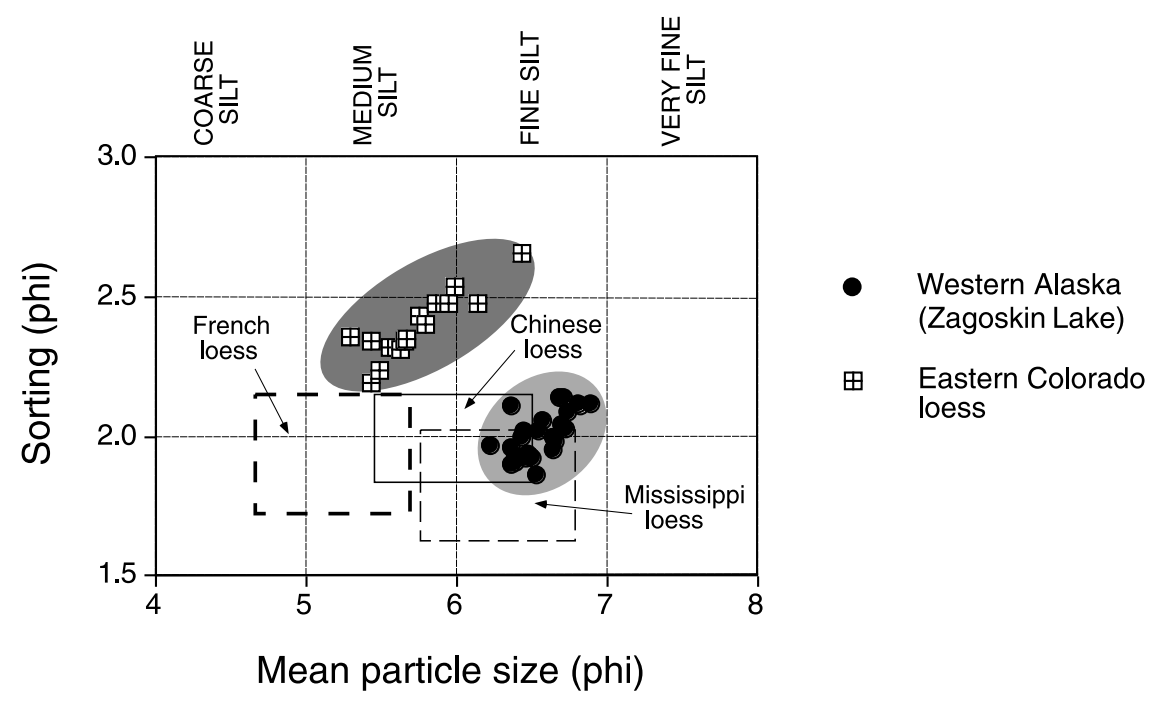

Fig. 5. Mean particle size and degree of sorting of Zagoskin Lake sediments compared to loess from Beecher Island, eastern Colorado (for locality, see Muhs et al., 1999) and ranges of values for loess from France, China and Mississippi. All analyses done by the laser diffraction method. Zagoskin Lake and eastern Colorado data from the present study; French, Chinese and Mississippi loess data are from Pye and Sherwin (1999).

ences in mineralogy between Zagoskin Lake sediments and the host basalt (Figs. 6,7). With one unexplained exception (SMI-4A), all rock samples we analyzed from St. Michael Island show $\mathrm{SiO}_{2}$ values of $48-52 \%$ (all major element values given herein are in weight percent), a typical range for basalt. $\mathrm{CaO}$ and $\mathrm{MgO}$ contents are relatively high (9$10 \%$ for $\mathrm{CaO} ; 5-7 \%$ for $\mathrm{MgO}$ ), which is also typical of basalts. $\mathrm{Fe}_{2} \mathrm{O}_{3}$ content (total $\mathrm{Fe}$ as $\mathrm{Fe}_{2} \mathrm{O}_{3}$ ) is over $10 \%$ in St. Michael Island basalts and the high plagioclase content of these rocks is shown by $\mathrm{Na}_{2} \mathrm{O}$ contents that are over $3 \%$.

In contrast to basalts of St. Michael Island, Zagoskin Lake sediments show a felsic composition. For major element contents of the lake sediments, we took bulk geochemical values and recalculated them on a biogenic-silica-

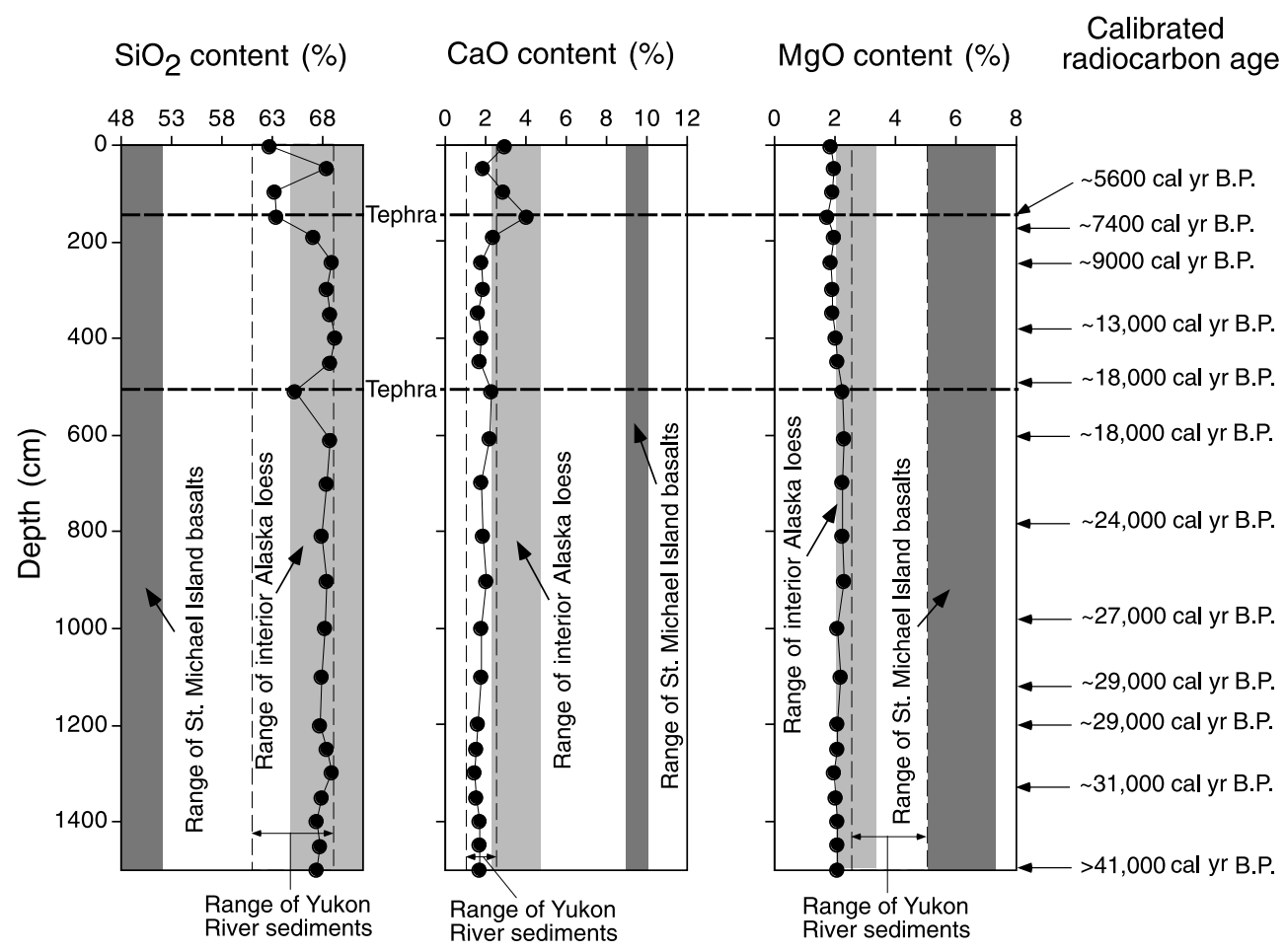

Fig. 6. Depth plots of $\mathrm{SiO}_{2}, \mathrm{CaO}$ and $\mathrm{MgO}$ in Zagoskin Lake sediments, with grey-shaded bands showing the range of these values in Fairbanks-area loesses (HH, GH, and HH localities of Fig. 1: see Muhs et al., 2003 for data) and St. Michael Island basalts (this study). Calibrated radiocarbon ages (Table 1) are also shown. 


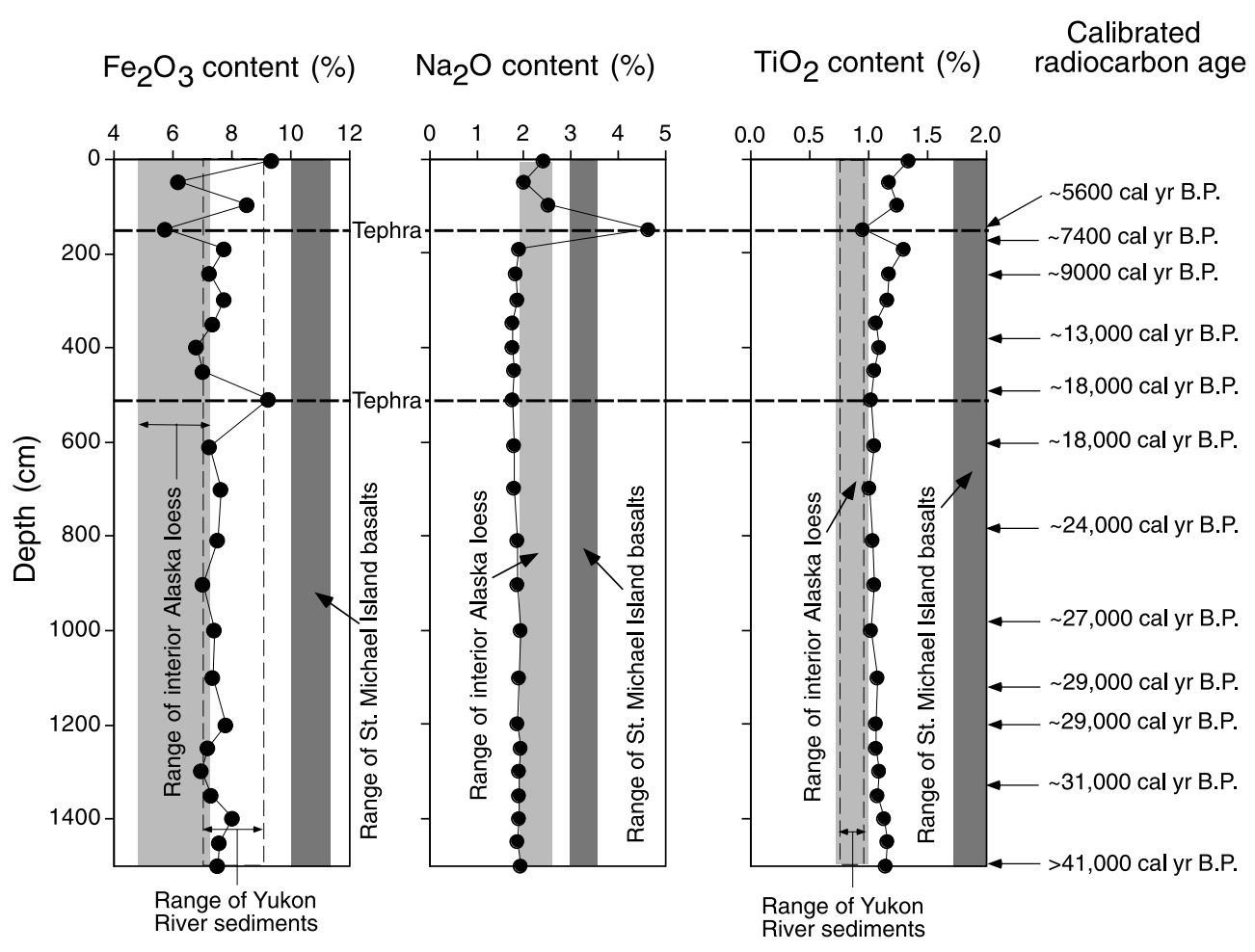

Fig. 7. Depth plots of $\mathrm{Fe}_{2} \mathrm{O}_{3}, \mathrm{Na}_{2} \mathrm{O}$, and $\mathrm{TiO}_{2}$ in Zagoskin Lake sediments, with grey-shaded bands showing the range of these values in Fairbanks-area loesses (HH, GH, and HH localities of Fig. 1: see Muhs et al., 2002 for data) and St. Michael Island basalts (this study). Calibrated radiocarbon ages (Table 1) are also shown.

free and volatile (mostly organic matter)-free basis. Thus, the major element values plotted for lake sediments in Figures 6 and 7 reflect the abundances of these elements in rock-forming minerals only and are directly comparable to the island basalts. For comparison, we also plotted the range of values for major elements in upland loesses (dated to less than $\sim 30,000$ yr B.P.) from central Alaska near Fairbanks (at the Gold Hill, Halfway House and Birch Hill localities: see Fig. 1) and fluvial sediments of the Yukon River, collected near the river's delta (Fig. 2), reported by Feely et al. (1981). Zagoskin Lake sediments have volatile- and biogenic silica-free $\mathrm{SiO}_{2}$ values that range from $63-68 \%$, which are very similar to values for Fairbanks-area loesses and Yukon River sediments. $\mathrm{CaO}$ and $\mathrm{MgO}$ contents are between 2-4\% for Zagoskin Lake sediments, also similar to Fairbanks-area loesses and Yukon River sediments, but much lower than St. Michael Island basalts. Most Zagoskin Lake sediments have $\mathrm{Na}_{2} \mathrm{O}$ contents of just under $2 \%$, which is within the lower range of values of Fairbanks loesses, but much lower than the local basalt.

The only Zagoskin Lake sediments that show somewhat less felsic compositions are tephras, both of which are easily visible in the core. Ager (1982) earlier identified two tephras in his core from nearby Puyuk Lake on St. Michael Island. In Puyuk Lake, the uppermost tephra is dated as late Holocene (estimated to be between 4,000 and $3,400{ }^{14} \mathrm{C}$ yr B.P.: see Begét et al., 1992) and was derived from Aniakchak Crater on the Alaska Peninsula (Riehle et al., 1987). The lower tephra in Puyuk Lake (ca. $15,000-16,000{ }^{14} \mathrm{C}$ yr B.P.) has not been linked to a known source vent. Both of these tephras were also found in the Zagoskin Lake core, in similar stratigraphic positions. In Zagoskin Lake, both tephras are depleted in $\mathrm{SiO}_{2}$ compared to the bulk of the core's sediments; the Aniakchak tephra is also enriched in $\mathrm{CaO}$ and $\mathrm{Na}_{2} \mathrm{O}$ (Figs. 6, 7).

We sampled eolian silts from other western Alaska localities for comparison with Zagoskin Lake silts. Loess in the central Seward Peninsula of western Alaska is thin and most of it probably dates to the last glacial period. In twenty exposures or shallow pits we examined in the central Seward Peninsula (Fig. 2), loess was typically about 35-45 $\mathrm{cm}$ thick, although shallow permafrost precluded deeper excavation at many localities. In this same area of the Seward Peninsula, McCulloch and Hopkins (1966) reported a minimum-limiting radiocarbon age of $8350 \pm 200{ }^{14} \mathrm{C}$ yr B.P. for the youngest loess. In the nearby Kigluaik Mountains (Fig. 2), Kaufman and Calkin (1988) inferred that moraines with a minimum radiocarbon age of 11,530 \pm 450 ${ }^{14} \mathrm{C}$ yr B.P. date to the late Wisconsin period. These moraines lack a loess cover, but all older moraines are mantled with loess. From these age relations, we infer that the shallow loess deposits examined in the central Seward Peninsula date to the late Wisconsin period.

Terrestrial sediments that were deposited during the last glacial period are common over much of the now-submerged Bering Shelf, including Norton Sound. The compo- 

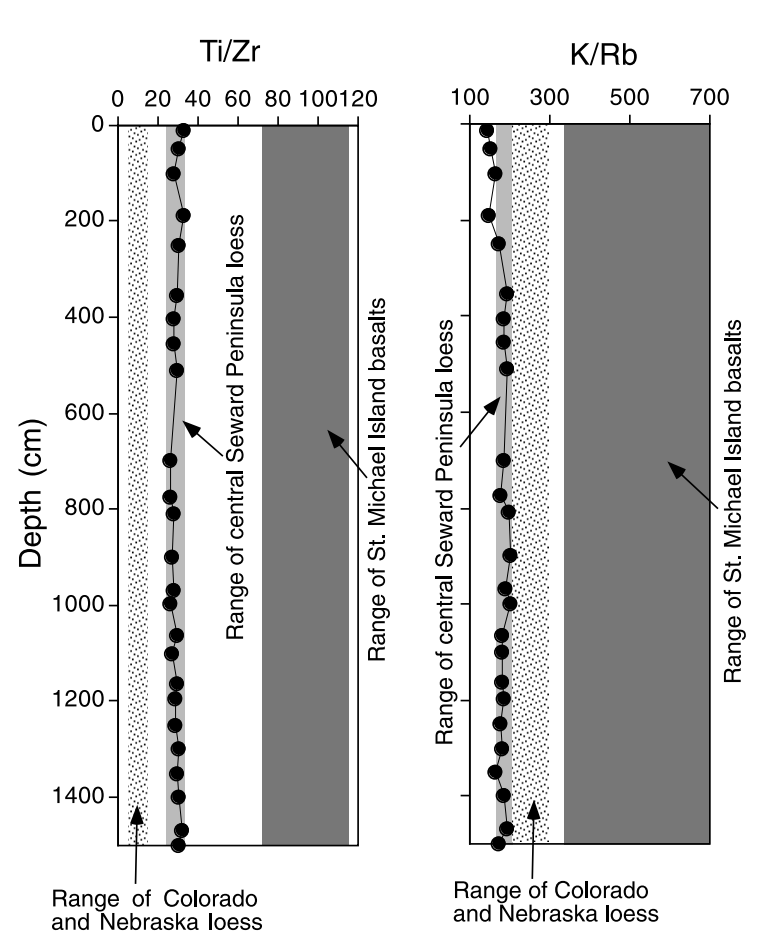

Calibrated
radiocarbon age
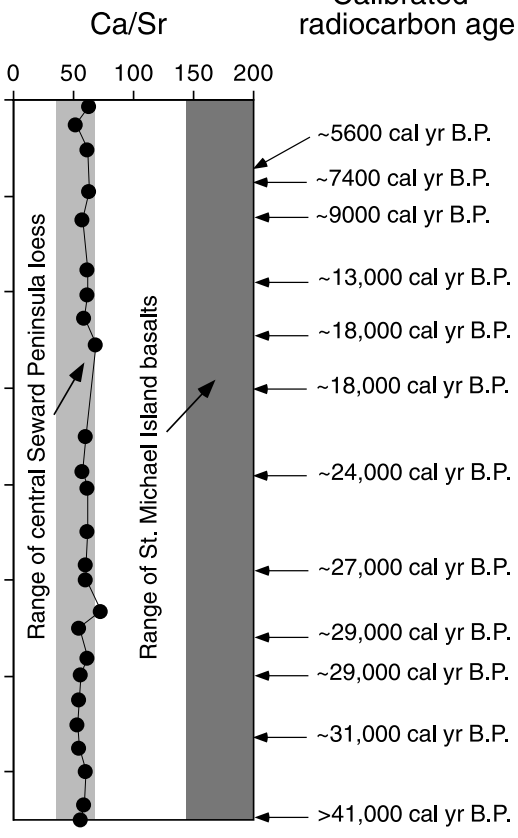

Fig. 8. Depth plots of Ti/Zr, $\mathrm{K} / \mathrm{Rb}$ and $\mathrm{Ca} / \mathrm{Sr}$ in Zagoskin Lake sediments, with stippled and grey-shaded bands showing the range of these values in Nebraska and Colorado loesses (data from Muhs et al., 1999), central Seward Peninsula loess (this study) and St. Michael Island basalts (this study). Calibrated radiocarbon ages (Table 1) are also shown.

sition of Norton Sound sediments that date to the last glacial period was studied from deposits in USGS core 76-121 (Fig. 2), raised from a depth of $\sim 17 \mathrm{~m}$. The uppermost part of the core contains fossiliferous marine sediments, but the lower $\sim 160$-cm-core segment contains nonmarine silts. The uppermost nonmarine silts have peat laminations, but the lowermost nonmarine sediments are massive, olive-greybrown silts that we interpret to be loess. For the lowermost silts from this core, Elias et al. (1996) reported bracketing radiocarbon ages of 11,570 \pm 130 (upper) and 29,500 \pm 340 (lower) ${ }^{14} \mathrm{C}$ yr B.P. We compared the composition of Zagoskin Lake sediments, loess collected from the central Seward Peninsula, and sediments in the Norton Sound core (Fig. 2) to determine if the three sediment groups had a common, eolian origin, distinct from the basalt.

Comparison of Zagoskin Lake sediments with other late Wisconsin eolian silts from western Alaska was made with selected major elements and complementary trace elements. Trace elements can provide useful information for sediment provenance and have been used recently for contrasting the compositions of eolian sediments in the North American midcontinent (e.g., Muhs et al., 1999). Ti/Zr values in sediments have been used extensively because these elements occur in different minerals and neither are easily soluble in most near-surface environments. Trace elements can also be used in combination with major elements that are found in the same minerals. For example, $\mathrm{Sr}$ substitutes for $\mathrm{Ca}$ in Ca-bearing minerals, such as calcic plagioclase, and $\mathrm{Rb}$ substitutes for $\mathrm{K}$ in $\mathrm{K}$-feldspar and mica. $\mathrm{Rb}$ tends to be enriched in late-formed K-bearing minerals. Thus, $\mathrm{Ca} / \mathrm{Sr}$ and $\mathrm{K} / \mathrm{Rb}$ values give distinctive signatures for sediments derived from different parent rocks.

Zagoskin Lake sediments have $\mathrm{Ti} / \mathrm{Zr}$ values that are distinct from the basalt on St. Michael Island (Fig. 8). These values are slightly higher than those from midcontinental North America loesses, but are indistinguishable from values in central Seward Peninsula loess. $\mathrm{K} / \mathrm{Rb}$ and $\mathrm{Ca} / \mathrm{Sr}$ values in Zagoskin Lake sediments are also indistinguishable from central Seward Peninsula loesses, but are significantly lower than from the island basalts. Thus, the trace element data support the interpretation made from major elements that local basalt is not the source of Zagoskin Lake silts.

It is interesting to note that elsewhere on the Seward Peninsula, loesses may have a basaltic source. Hopkins (1963) reported that loess that overlies basalt near Imuruk Lake (Fig. 2) has scarce quartz, but fair amounts of plagioclase, suggesting a dominance of local basalt as the source. Although we lack mineralogical data for the central Seward Peninsula loesses reported here, the Ti/Zr, K/Rb and $\mathrm{Ca} / \mathrm{Sr}$ values of these sediments all suggest felsic source rocks.

Norton Sound sediments from USGS core 76-121 (Fig. 2) are massive and have a silt-dominated particle size in the lower part of the core that dates to the last glacial period (Fig. 9). During this time interval ( $\sim 33,000-13,000$ cal yr B.P.), sea level was well below the present 17-m depth where the core was raised (Fairbanks, 1989; Bard et al., 1990; Yokoyama et al., 2001). We interpret the massive silts 

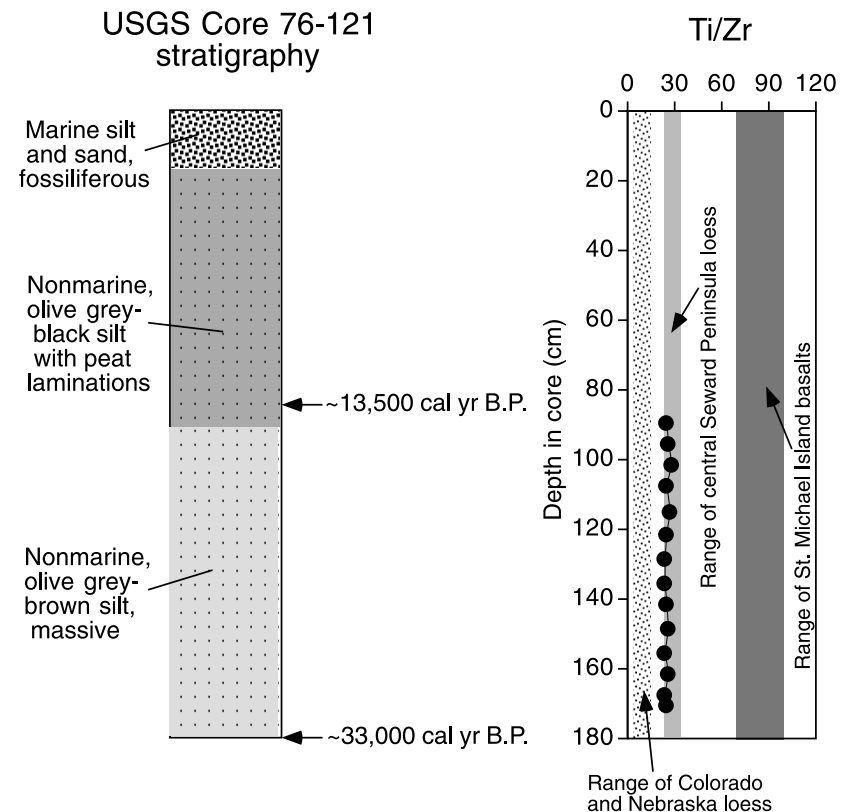
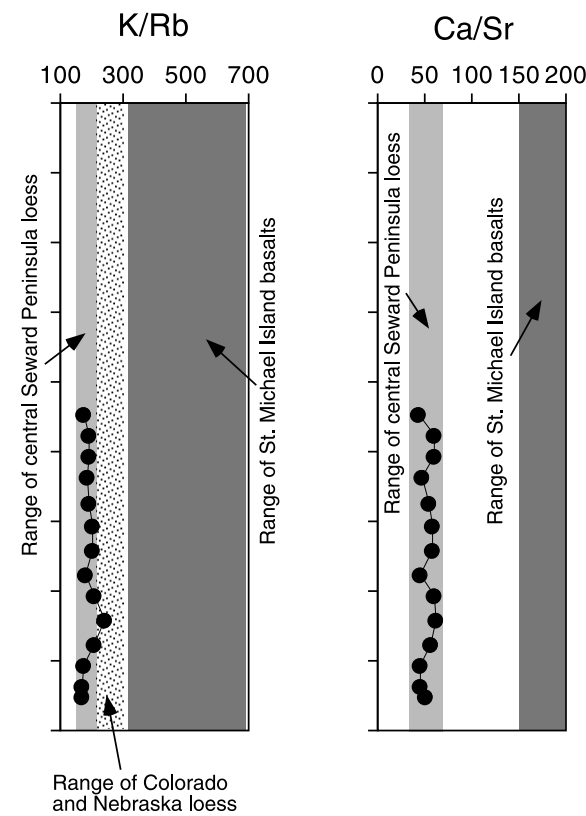

Fig. 9. Depth plots of $\mathrm{Ti} / \mathrm{Zr}, \mathrm{K} / \mathrm{Rb}$ and $\mathrm{Ca} / \mathrm{Sr}$ in Norton Sound core sediments, with stippled and grey-shaded bands showing the range of these values in Nebraska and Colorado loesses (data from Muhs et al., 1999), central Seward Peninsula loess (this study) and St. Michael Island basalts (this study). Calibrated radiocarbon ages (Elias et al., 1996) are also shown.

of last-glacial age in core $76-121$ to be loess and further infer that they may have been deposited during the same period as Zagoskin Lake silts and central Seward Peninsula loess. Ti/Zr, $\mathrm{K} / \mathrm{Rb}$ and $\mathrm{Ca} / \mathrm{Sr}$ values in the Norton Sound sediments are indistinguishable from those in central Seward Peninsula loess and Zagoskin Lake sediments (Figs. $8,9)$.

\section{Discussion}

Particle size and major element data show that Zagoskin Lake sediments are not derived from the local island basalt and are of eolian origin. Furthermore, similar ranges of values for $\mathrm{Ti} / \mathrm{Zr}, \mathrm{K} / \mathrm{Rb}$ and $\mathrm{Ca} / \mathrm{Sr}$ in Zagoskin Lake sediments, Norton Sound sediments and central Seward Peninsula loess imply a common eolian origin from a felsic rock source or sources, distinct from western Alaskan basalts. Identification of the specific source or sources of these eolian silts is beyond the scope of this paper and would likely require the use of isotopic methods, such as Aleinikoff et al. (1999) used for identification of loess sources in eastern Colorado. Nevertheless, some inferences about possible source sediments can be made from an examination of loess distribution in the region.

The distribution of loess in Alaska shows that much eolian silt is found to the south, west or southwest of the major rivers of the region (Fig. 1). Although there are exceptions to this generalization, large loess bodies occur to the southwest of the Kobuk, Koyukuk, Yukon and Kuskokwim Rivers in the western half of the state. All of these rivers drain mountainous areas that were extensively glaciated in the Pleistocene. Studies of contemporary drainage systems in Alaska show that sediment yields are significantly greater in glacierized basins than in non-glacierized basins (Hallett et al., 1996). We infer from these observations, plus the spatial distribution of loess bodies, that glaciogenic silt carried by the region's major rivers was the major source of loess in the western half of Alaska. If this interpretation is correct, then northeasterly winds may have entrained glaciogenic silts from the Noatak, Kobuk, and Koyukuk Rivers, as well as the middle reaches of the Yukon River. Major element composition of Yukon River sediments supports an interpretation that this river may have been an important source of western Alaskan loess (Figs. $6,7)$.

Northeasterly paleowinds are consistent with inferences of similar paleowinds from full-glacial and/or late-glacialage eolian sands studied by Hopkins (1982) and Lea and Waythomas (1990). Hopkins (1972) hypothesized that a persistent high pressure cell might have developed over the Arctic Ocean during the last glacial period. He speculated that strong easterly or northeasterly winds, generated by this high pressure, would have swept over Alaska and Siberia in summer. The pattern of loess and eolian sand distribution would seem to support this hypothesis. However, a recent climate model suggests that during late-glacial time ( 16,000-11,000 cal yr B.P.), summer surface winds in Alaska and eastern Siberia would have been from the southwest, due to a strengthened subtropical high pressure system over the North Pacific Ocean (Bartlein et al., 1998). Thus, either most loess deposition took place during seasons other 


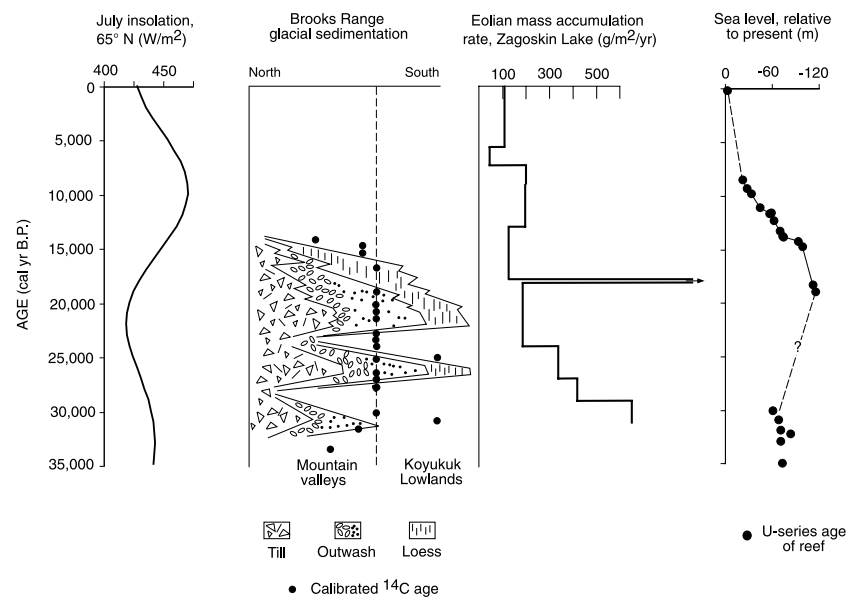

Fig. 10. Plots showing variation in July insolation at $65^{\circ} \mathrm{N}$ latitude (Berger and Loutre, 1981), glacial and sedimentation history of the Brooks Range, Alaska (Hamilton, 1982), mass accumulation rates (MAR) of eolian silt in Zagoskin Lake, Alaska (this study) and global sea level (Fairbanks, 1989; Bard et al., 1990; Yokoyama et al., 2001) for the past $\sim 35,000$ cal yr B.P. Note that the extraordinarily high MAR at $\sim 18,000$ cal yr B.P. $(\sim 3400$ $\mathrm{g} / \mathrm{m}^{2} / \mathrm{yr}$ ) may be closer to $500-600 \mathrm{~g} / \mathrm{m}^{2} / \mathrm{yr}$ if one radiocarbon age is too young (see discussion in text).

than summer, which seems unlikely, or there is a serious disagreement with computer-simulated paleowinds and those inferred from the geologic record.

Another possibility is that most loess deposition in western Alaska took place during full-glacial time, around $21,000 \mathrm{cal}$ yr B.P., when the modeled southwesterly winds in Bartlein et al. (1998) are much weaker than during lateglacial time (ca. 16,000-11,000 cal yr B.P.). Such an explanation would suggest, therefore, that silts in the lower part of the Zagoskin Lake core would have been derived from a source which lay to the northeast and silts in the upper part of the core would have been derived from a source which lay to the southwest. Key major-to-trace element ratios do not suggest any significant change in sources (Fig. 8). However, because of the course it takes, the Yukon River could have been a loess source whether winds were from the northeast or southwest (Fig. 1).

Whatever their source or sources may have been, Zagoskin Lake sediments show abundant eolian silt accumulation during the last glacial period, in contrast to central Alaska. We estimated mass accumulation rates (MARs), in $\mathrm{g} \mathrm{m}^{-2} \mathrm{yr}^{-1}$, between the midpoints of radiocarbon-dated intervals using the mineral fraction (i.e, that part of the sediment that is not biogenic silica or organic matter) of the core sediment. In making these calculations, we assumed a bulk density of $\sim 0.63 \mathrm{~g} \mathrm{~cm}^{-3}$, an average value for other Alaskan lake sediments (Anderson et al., 2001a, 2001b). In general, eolian silt MARs for St. Michael Island are higher during the last glacial period than during the Holocene (Fig. 10), but there is significant variability within the last glacial period. During a short interval of less than $\sim 200 \mathrm{yr}$ around $18,000 \mathrm{cal}$ yr B.P., the MAR could have been as high as $\sim 3400 \mathrm{~g} \mathrm{~m}^{-2} \mathrm{yr}^{-1}$. However, this extraordinary MAR occurs in the core depth (490-500 cm; sample W-4928) where Ager (this volume) has doubts about the reliability of the radiocarbon age, as noted earlier. Thus, the true MAR for this depth interval could be lower by as much as a factor of six. For other intervals in the last glacial period, rates vary from $\sim 125$ to $\sim 700 \mathrm{~g} \mathrm{~m}^{-2} \mathrm{yr}^{-1}$. These rates of accumulation are comparable to last-glacial loess MARs that have been calculated for areas near the Brooks Range and the northern Seward Peninsula (Muhs et al., 2003). In addition, Zagoskin Lake eolian silt MARs are two-to-three orders of magnitude higher than those reported for eolian silt found in many deep-sea cores and all ice cores, and are as high or higher than last-glacial loess MARs on the Chinese Loess Plateau (Kohfeld and Harrison, 2001). In fact, assuming a typical loess bulk density of $\sim 1.45 \mathrm{~g} \mathrm{~cm}^{-3}$, the eolian silt component of Zagoskin Lake sediments would imply a subaerial accumulation of several meters of loess in the last-glacial period. Field observations on St. Michael Island by Hoare and Condon (1971), as well as by ourselves, indicate that only about a meter of loess has accumulated on the island. Sediment focusing in the lake bottom (i.e., greater localized accumulation rates because of reworking of sediments into deep basins in the lake) may explain some of these higher MARs. Nevertheless, sediment focusing seems insufficient to explain all of the apparent high rates of silt accumulation. The lake basin is funnelshaped, with a broad, fairly flat bottom.

We hypothesize that the nature of the vegetation cover in western Alaska during full-glacial time is responsible for the apparent contradiction of high MARs in Zagoskin Lake but little subaerial loess accumulation on St. Michael Island. Pollen, plant macrofossil, and pedologic data allow reconstruction of vegetation during the last-glacial period in western Alaska. Studies conducted over the region, extending from south of the Yukon Delta to at least the northern Seward Peninsula and St. Lawrence Island (Figs. 1, 2), show that vegetation during the last glacial period was dominated by a dry, sparse herb tundra (Colinvaux, 1964, 1967; Ager, 1982, 1983 and this volume; Höfle et al., 2000; Goetcheus and Birks, 2001). Elsewhere in Alaska, herb tundra was also the dominant vegetation in full-glacial time (Ager, 1983; Ager and Brubaker, 1985). The sparseness of the vegetation cover in western Alaska during full-glacial time is suggested by pollen of "pioneer" plants, which can colonize bare or frost-disturbed soils. Examples of such plants include Plantago, Brassicaceae, Caryophyllaceae and various species of Asteraceae (Ager, 1982 and this volume). The significance of a herb tundra vegetation with discontinuous plant cover and many pioneer species is that there would be little ability for vegetation to trap and retain eolian silt. Pioneer plants indicate a sparse vegetation cover, but in addition have low roughness heights, as with other herb tundra plants. Tsoar and Pye (1987) have shown that variability in roughness heights for different vegetation communities explains different loess-trapping abilities. Herb tundra vegetation has a very low roughness height, even 
lower than grass and more than an order of magnitude lower than forest. As a result, upland regions, including those in both western and central Alaska, would have had a lower dust-trapping capability compared to the present boreal forest (central Alaska) or shrub tundra (western Alaska). Bare bedrock surfaces would be the least efficient loess traps of all, because it is vegetation of any kind, with its increase in surface roughness, that allows much of the eolian shear stress to be imparted to the plant cover. In contrast, water bodies such as lakes are efficient and permanent loess traps (Tsoar and Pye, 1987). Based on these observations, the thick, last-glacial eolian silt accumulation in Zagoskin Lake compared to the loess record on land is consistent with Ager's (this volume) evidence for a discontinuous cover of low, herb tundra vegetation.

The timing of maximum rates of eolian silt deposition in Zagoskin Lake, compared to the Alaskan glacial record, has implications for the dominant control on silt particle generation. It has been assumed by most Alaskan Quaternary geologists that glaciers are the primary source of silt-sized particles found in loess. Although this has been a timehonored concept for many decades (see Péwé, 1975), it has been challenged recently (Wright, 2001). Eolian silt deposition in Zagoskin Lake occurred during the Holocene, but at lower rates than during the Pleistocene (Fig. 10). In the period from $\sim 30,000-15,000$ cal yr B.P., glaciers were much more extensive in Alaska than they are now (Hamilton, 1994). In Zagoskin Lake, relatively high Pleistocene MARs occur at $\sim 30,000,27,000-24,000$, and 18,000 cal yr B.P., which correspond to the waning stages of three distinct late Wisconsin ice advances in the southern Brooks Range (Hamilton, 1982: Fig. 10). This correspondence, combined with the observation that modern glacierized basins in Alaska yield more sediment than non-glacierized basins (Hallett et al., 1996) argues that silt, produced by glaciers and released in outwash sediments, is the most important source for loess.

\section{Summary}

Particle size and geochemical data indicate that the mineral fraction of Zagoskin Lake sediment in western Alaska is not derived from the local basaltic bedrock but is eolian silt from distant sources. Eolian silt deposition took place at varying rates from at least the latter part of the mid-Wisconsin interstadial period through the Holocene. This finding shows that basaltic maar lakes hold considerable potential as record-keepers for long-term eolian sedimentation. Geochemical data from the Zagoskin Lake core, sediments cored from Norton Sound, and central Seward Peninsula loess show that all three deposits could have had a common eolian origin from a felsic rock source. Loess distribution in western Alaska and the geochemistry of Yukon River sediments suggest that alluvium, deflated by northeasterly winds, could have been the source of eolian silt. This hy- pothesis needs additional testing, but if true, it disagrees with a climate model simulation that suggests dominant winds were from the southwest (Bartlein et al., 1998).

Eolian mass accumulation rates in Zagoskin Lake were higher during Pleistocene time than during Holocene time. Much more eolian sediment is preserved as lake sediment than as loess on the adjacent landscape. This discrepancy may be due to the inefficient loess-trapping and holding ability of a sparse, herb tundra vegetation that dominated the landscape in full-glacial time. Despite the higher average Pleistocene mass accumulation rates, there is considerable variation in the rate of eolian deposition in Zagoskin Lake during the last glacial period. The highest rates of eolian deposition seem to have occurred during late-glacial or deglacial periods $(\sim 30,000,27,000-24,000$, and 18,000 cal yr B.P.), when abundant sediment would have been available as outwash from glaciated mountainous areas. If this correlation is valid, then it challenges recent assertions that glaciers do not have as important a role in loess formation as previously thought.

\section{Acknowledgments}

We thank John Westgate, University of Toronto, for inviting us to contribute this paper. The study was supported by the Earth Surface Dynamics Program of the U.S. Geological Survey and is a joint contribution from the "Eolian History of North America" and "Ecosystem History of Southern Alaska" Projects. Mark Thompson (resident and schoolteacher on St. Michael Island) and his students kindly collected samples of the island's basalt for us. Several U.S. Geological Survey colleagues provided valuable data used in this study. We thank Steve Colman (biogenic silica data), Gary Skipp (X-ray mineralogy), Eric Fisher (laser diffraction granulometry), Brain Marshall (trace element geochemistry), Larry Phillips (Norton Sound core description) and Lea Gargulinski and Meyer Rubin (radiocarbon ages). We appreciate helpful reviews of an earlier version of the paper by Rick Forester, John Whitney, Julie Brigham-Grette and Dan Mann. Thanks also go to John Westgate for careful editing. We dedicate this paper to the late Troy L. Péwé and David M. Hopkins, two pioneers of Alaskan Quaternary geology whose work has inspired us.

\section{References}

Ager, T.A., 1982. Vegetational history of western Alaska during the Wisconsin glacial interval and the Holocene, in: Hopkins, D.M., Matthews Jr., J.V., Schweger, C.E., Young, S.B. (Eds.), Paleoecology of Beringia, Academic Press, New York, pp. 75-93.

Ager, T.A., 1983. Holocene vegetational history of Alaska, in: Wright Jr., H.E. (Ed.), Late-Quaternary Environments of the United States Volume 2 The Holocene, University of Minnesota Press, Minneapolis, pp. $128-141$. 
Ager, T.A., 2003. Late Quaternary vegetation and climate history of the central Bering land bridge from St. Michael Island, western Alaska. Quaternary Research, this volume.

Ager, T.A., Brubaker, L., 1985. Quaternary palynology and vegetational history of Alaska, in: Bryant Jr., V.M., Holloway, R.G. (Eds.), Pollen Records of Late-Quaternary North American Sediments, American Association of Stratigraphic Palynologists Foundation, Dallas, Texas, pp. 353-383.

Aleinikoff, J.N., Muhs, D.R., Sauer, R., Fanning, C.M., 1999. Late Quaternary loess in northeastern Colorado, Part II-Pb isotopic evidence for the variability of loess sources. Geological Society of American Bulletin 111, 1876-1883.

Anderson, L., Abbott, M.B., and Finney, B.P., 2001a. Alaska lake sediment data and Holocene climate reconstructions. IGBP PAGES World Data Center for Paleoclimatology (Boulder, Colorado), Data Contribution Series, 2001-038.

Anderson, L., Abbott, M.B., Finney, B.P., 2001b. Holocene climate inferred from oxygen isotope ratios in lake sediments, central Brooks Range, Alaska. Quaternary Research 55, 313-321.

Bard, E., Hamelin, B., Fairbanks, R.G., Zindler, A., 1990. Calibration of the ${ }^{14} \mathrm{C}$ timescale over the past 30,000 years using mass-spectrometric U-Th ages from Barbados corals. Nature 345, 405-410.

Bartlein, P.J., Anderson, K.H., Anderson, P.M., Edwards, M.E., Mock, C.J., Thompson, R.S., Webb, R.S., Webb III, T., Whitlock, C., 1998. Paleoclimate simulations for North America over the past 21,000 years: features of the simulated climate and comparisons with paleoenvironmental data. Quaternary Science Reviews 17, 549-585.

Begét, J.E., 1988. Tephras and sedimentology of frozen loess. International Permafrost Conference Proceedings 5, 672-677.

Begét, J.E., 1990. Middle Wisconsin climate fluctuations recorded in central Alaskan loess. Géographie Physique et Quaternaire 44, 3-13.

Begét, J., Mason, O., Anderson, P., 1992. Age, extent and climatic significance of the c. 3400 BP Aniakchak tephra, western Alaska, USA. The Holocene 2, 51-56.

Begét, J.E., Hopkins, D.M., Charron, S.D., 1996. The largest known maars on Earth, Seward Peninsula, northwest Alaska. Arctic 49, 62-69.

Berger, A., Loutre, M.F., 1991. Insolation values for the climate of the last 10 million years. Quaternary Science Reviews 10, 297-317.

Bradbury, J.P., Grosjean, M., Stine, S., Sylvestre, F., 2001. Full and late glacial lake records along the PEP 1 transect: their role in developing interhemispheric paleoclimate interactions, in: Markgraf, V. (Ed.), Interhemispheric Climate Linkages, Academic Press, San Diego, pp. 265-291.

Buurman, P., Pape, Th., Muggler, C.C., 1997. Laser grain-size determination in soil genetic studies 1. Practical Problems. Soil Science 162, 211-218.

Colinvaux, P.A., 1964. The environment of the Bering Land Bridge Ecological Monographs 34, 297-329.

Colinvaux, P.A., 1967. A long pollen record from St. Lawrence Island, Bering Sea, Alaska. Palaeogeography, Palaeoclimatology, Palaeoecology 3, 29-48.

Colman, S.M., Peck, J.A., Karabanov, E.B., Carter, S.J., Bradbury, J.P., King, J.W., Williams, D.F., 1995. Continental climate response to orbital forcing from biogenic silica records in Lake Baikal. Nature 378, $769-771$.

Dean, W.E., 1997. Rates, timing, and cyclicity of Holocene eolian activity in north-central United States: evidence from varved lake sediments. Geology 25, 331-334.

Elias, S.A., Short, S.K., Nelson, C.H., Birks, H.H., 1996. Life and times of the Bering Land Bridge. Nature 382, 60-63.

Fairbanks, R.G., 1989. A 17,000-year glacio-eustatic sea level record: influence of glacial melting rates on the Younger Dryas event and deep-ocean circulation. Nature 342, 637-642.

Feely, R.A., Massoth, G.J., Paulson, A.J., 1981. The distribution and elemental composition of suspended particulate matter in Norton Sound and the northeastern Bering Sea shelf: implications for Mn and Zn recycling in coastal waters, in: Hood, D.W., Calder, J.A. (Eds.), The
Eastern Bering Sea Shelf: Oceanography and Resources Volume One, U.S. Department of Commerce, National Oceanic and Atmospheric Administration, Washington, D.C, pp. 321-337.

Goetcheus, V.G., Birks, H.H., 2001. Full-glacial upland tundra vegetation preserved under tephra in the Beringia National Park, Seward Peninsula, Alaska. Quaternary Science Reviews 20, 135-147.

Hallett, B., Hunter, L., Bogen, J., 1996. Rates of erosion and sediment evacuation by glaciers: a review of field data and their implications. Global and Planetary Change 12, 213-235.

Hamilton, T.D., 1982. A late Pleistocene glacial chronology for the southern Brooks Range: stratigraphic record and regional significance. Geological Society of America Bulletin 93, 700-716.

Hamilton, T.D., 1994. Late Cenozoic glaciation of Alaska, in: Plafker, G., Berg, H.C. (Eds.), The Geology of Alaska, The Geology of North America, v. G-1. Geological Society of America, Boulder, Colorado, pp. 813-844.

Hoare, J.M., and Condon, W.H., 1971. Geologic Map of the St. Michael Quadrangle, Alaska. U.S. Geological Survey Miscellaneous Geologic Investigations Map I-682.

Höfle, C., Ping, C.-L., 1996. Properties and soil development of latePleistocene paleosols from Seward Peninsula, northwest Alaska. Geoderma 71, 219-243.

Höfle, C., Edwards, M.E., Hopkins, D.M., Mann, D.H., Ping, C.-L., 2000. The full-glacial environment of the northern Seward Peninsula, Alaska, reconstructed from the 21,500-year-old Kitluk paleosol. Quaternary Research 53, 143-153.

Hopkins, D.M., 1963. Geology of the Imuruk Lake area, Seward Peninsula, Alaska. U.S. Geological Survey Bulletin 1141-C, 101 pp.

Hopkins, D.M., 1972. The paleogeography and climatic history of Beringia during late Cenozoic time. Inter-Nord 12, 121-150.

Hopkins, D.M., 1982. Aspects of the paleogeography of Beringia during the late Pleistocene, in: Hopkins, D.M., Matthews Jr.. J.V., Schweger, C.E., Young, S.B. (Eds.), Paleoecology of Beringia, Academic Press, New York, pp. 3-28.

Kaufman, D.S., Calkin, P.E., 1988. Morphometric analysis of Pleistocene glacial deposits in the Kigluaik Mountains, northwestern Alaska, U.S.A. Arctic and Alpine Research 20, 273-284.

Kohfeld, K.E., Harrison, S.P., 2001. DIRTMAP: the geological record of dust. Earth-Science Reviews 54, 81-114.

Lea, P.D., Waythomas, C.F., 1990. Late-Pleistocene eolian sand sheets in Alaska. Quaternary Research 34, 269-281.

McCulloch, D., Hopkins, D., 1966. Evidence for an early Recent warm interval in northwestern Alaska. Geological Society of America Bulletin 77, 1089-1108.

Muhs, D.R., Bettis III, E.A., 2000. Geochemical variations in Peoria Loess of western Iowa indicate paleowinds of midcontinental North America during last glaciation. Quaternary Research 53, 49-61.

Muhs, D.R., Aleinikoff, J.N., Stafford Jr., T.W., Kihl, R., Been, J., Mahan, S.A., Cowherd, S.D., 1999. Late Quaternary loess in northeastern Colorado: Part I-Age and paleoclimatic significance. Geological Society of America Bulletin 111, 1861-1875.

Muhs, D.R., Ager, T.A., Bettis, III, E.A., McGeehin, J., Been, J.M., Begét, J.E., Pavich, M.J., Stafford, Jr., T.W., Pinney, D., 2003. Stratigraphy and paleoclimatic significance of late Quaternary loess-paleosol sequences of the last interglacial-glacial cycle in central Alaska. Quaternary Science Reviews, in press.

Péwé, T.L., 1955. Origin of the upland silt near Fairbanks, Alaska. Geological Society of America Bulletin 66, 699-724.

Péwé, T.L., 1975. Quaternary geology of Alaska. U.S. Geological Survey Professional Paper 835, 145 pp.

Pye, K., Sherwin, D., 1999. Loess, in: Goudie, A.S., Livingstone, I., Stokes, S. (Eds.), Aeolian Environments, Sediments and Landforms, John Wiley \& Sons, Ltd., Chicester, pp. 213-238.

Riehle, J.R., Meyer, C.E., Ager, T.A., Kaufman, D.S., Ackerman, R.E., 1987. The Aniakchak tephra deposit, a late Holocene marker horizon in western Alaska. U.S. Geological Survey Circular 998, 19-22. 
Sainsbury, C.L., 1972. Geologic Map of the Teller Quadrangle, Western Seward Peninsula, Alaska. U.S. Geological Survey Miscellaneous Geologic Investigations Map I-685, scale 1:250,000.

Stuiver, M., Reimer, P.J., Bard, E., Beck, J.W., Burr, G.S., Hughen, K.A., Kromer, B., McCormac, G., van der Plicht, J., Spurk, M., 1998 INTCAL 98 Radiocarbon age calibration, 24,000-0 cal BP. Radiocarbon 40, 1041-1083.

Tsoar, H., Pye, K., 1987. Dust transport and the question of desert loess formation. Sedimentology 34, 139-153.

Voelker, A.H.L., Grootes, P.M., Nadeau, M.-J., Sarnthein, M., 2000. Radiocarbon levels in the Iceland Sea from 25-53 kyr and their link to the Earth's magnetic field intensity. Radiocarbon 42, 437-452.
Westgate, J.A., Stemper, B.A., Péwé, T.L., 1990. A 3 m.y. record of Pliocene-Pleistocene loess in interior Alaska. Geology 18, $858-$ 861.

Wright, J.S., 2001. "Desert" loess versus "glacial" loess: quartz silt formation, source areas and sediment pathways in the formation of loess deposits. Geomorphology 36, 231-256.

Xiao, J.L., Inouchi, Y., Kumai, H., Yoshikawa, S., Kondo, Y., Liu, T.S., An, Z.S., 1997. Eolian quartz flux to Lake Biwa, central Japan, over the past 145,000 years. Quaternary Research 48, 48-57.

Yokoyama, Y., Esat, T.M., Lambeck, K., 2001. Coupled climate and sea-level changes deduced from Huon Peninsula coral terraces of the last ice age. Earth and Planetary Science Letters 193, 579-587. 